\title{
Assessment of the Integrity and Retention of Chromium (VI) in Portland Cement Pastes
}

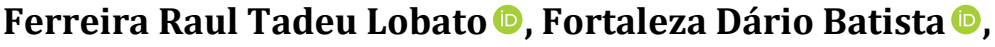 \\ Amorim Kelly Aparecida da Encarnação ${ }^{\circledR}$, Lira Fernanda Silva ${ }^{(0)}$, Silva Marizete Helena Pereira, \\ Wagner Batista Santos
}

Institute of Exact Sciences and Earth, Federal University of Mato Grosso, Barra do Garças/MT, Brazil

Email: raullobato@ufmt.br,wbsantos@ufmt.br

How to cite this paper: Lobato, F.R.T., Batista, F.D., da Encarnação, A.K.A., Silva, L.F., Pereira, S.M.H. and Santos, W.B. (2021) Assessment of the Integrity and Retention of Chromium (VI) in Portland Cement Pastes. Advances in Chemical Engineering and Science, 11, 1-17.

https://doi.org/10.4236/aces.2021.111001

Received: September 1, 2020

Accepted: November 27, 2020

Published: November 30, 2020

Copyright (c) 2021 by author(s) and Scientific Research Publishing Inc. This work is licensed under the Creative Commons Attribution-NonCommercial International License (CC BY-NC 4.0). http://creativecommons.org/licenses/by-nc/4.0/

\begin{abstract}
Chromium is a heavy metal used for various applications such as in the manufacture of stainless steels, in chemicals for wood treatment, in tanneries, and in the refractory industry. The main problem associated with the use of chromium in these activities is the considerable volume of contaminated effluent that requires treatment, mainly due to its high mobility and toxicity in its hexavalent form. Immobilization methods arise as an efficient solution for the treatment of these wastes through converting them into inert and stable materials. The present paper aims to investigate Portland cement II's paste properties with potassium dichromate addition in order to verify the chromium immobilization process. Analyses of moisture content, water absorption, axial compressive strength, and solubilization were done in samples at 7 and 28 days with $0 \% ; 0.5 \% ; 1.05 ; 1.5 \% ; 2.0 \%$ and $2.5 \%$ potassium dichromate addition. The results showed the influence of this salt in cement hydration reactions, damaging the mechanical behavior and the water absorption capability of the material produced. In the solubilization test, all compositions had $>99 \%$ efficiency of chromium immobilization in both ages of hydration, thus demonstrating the capability of a cementitious matrix to stabilize this metal.
\end{abstract}

\section{Keywords}

Wastes, Solidification-Stabilization, Chromium, Solubilization

\section{Introduction}

Industrial development and population growth over the last years have relevantly affected waste production. According to Vieira et al., [1] industrial activities produce a huge variety of solid, liquid, and gaseous waste, which may or may not 
return to the production process as power sources, as feedstock materials, or to be marketed as resources for other industrial activities. The NBR 10004 [2] states that a waste is classified as hazardous when it's flammable, corrosive, reactive, toxic, or pathogenic, as is the case with heavy metals. Such metals are of essential importance in small quantities for some biological systems, but a great part of these metals, which fall within this group, are toxic to human beings even in low concentrations [3] [4]. Chromium is a heavy metal used in several processes, such as for the fabrication of stainless steels and other metal alloys, in chemical products for wood treatment, in tanneries, and in the refractory industry [5]. The main problem associated with the use of chromium for these activities is the significant volume of contaminated effluents that require treatment, mainly due to its high mobility and toxicity within its hexavalent form [4] [6] [7].

There are various forms of treatment, which differ in terms of cost and efficiency. However, most of these methods engender highly contaminated materials as products, either in the form of sludge or as precipitated materials [8]. According to Guo et al., [9] the safe disposal of these materials is an important task for environmental protection, since the poor management of this type of residue offers a series of risks to the environment. Amongst the immobilization methods, thermal treatments and solidification-stabilization methods should be highlighted. In accordance with Chen et al., [10] the solidification process consists of the acquirement of a solid residual form that may or may not have chemical links between the contaminants and the cementitious material. In accord with Brehm et al., [11] the immobilization methods allow the reuse of waste as a raw material in the civil construction industry, and thus enable the cost reduction for treatment and final disposal, with a reduction of the area required for grounding.

Hexavalent chromium is also found in concrete, one of the most used construction materials in the world, derived from the oxidation of trivalent chromium during the Portland cement manufacturing process [12] [13]. The presence of chromium in cement is due to the presence of this element in the raw material itself and in additions, which may contain chromium in its composition (clinker and fly ash), and due to the manufacturing process (grinder wear) [14] [15] [16].

However, the use of Portland cement is very common in these treatments, mainly because of the well characterized hydration process that happens during solidification [11] [17] [18] [19]. During the immobilization process, the residues may simply act as aggregates (inert) or react with the components of the cement [8]. Stegemann \& Zhou [20] state that some contaminants present in industrial waste may have a detrimental effect in cements, causing retention failures, which highlights the importance of laboratory tests to predict the performance of the product obtained by the procedure of stabilization through solidification. In this aspect, the importance of investigations on the products properties obtained through these treatments is noted, especially those that refer to the efficiency of the immobilization process and that allow the evaluation of 
the possibility of using such materials in other industries. Therefore, this work aimed to evaluate Portland cement's efficiency as a solidifying agent in the immobilization of chromium (VI), investigating the effects of potassium dichromate's addition on the solidified product's mechanical properties; the effectiveness of the solidification-stabilization process, using durability and solubilization tests; and the healing time influence on the efficiency of the treatment.

\section{Experimental Section}

\subsection{Materials}

Potassium dichromate: As a contamination source of hexavalent chromium, commercial potassium dichromate salt $\left(\mathrm{K}_{2} \mathrm{Cr}_{2} \mathrm{O}_{7}\right)$ with molar mass $=294.18$ $\mathrm{g} / \mathrm{mol}$ and purity $=99 \%$ was used. The salt did not suffer any kind of pre-treatment preceding the test specimen preparation. The choice of potassium dichromate in this work is justified to the fact that the chromium is a heavy metal and high concentrations classify the material as dangerous, it is still an element present in the activities of tanneries to prevent leather putrefaction in Brazil.

Cement: The cement utilized was Portland cement composed of pozzolanic material, classified by NBR 16697 [21] as CP II-Z 32. This type of cement was utilized because of its huge market availability and propagated use [22]. The compositional limits specified by the standard are presented in Table 1.

\subsection{Methods}

Since the objective of the research was to verify the chromium influence on the properties of cement, it was decided to work with test specimens made with paste instead of concrete or mortar. This decision reduced the number of variables involved in the evaluated properties and contributed to the reduction of the waste volume generated through the development of the work. Test specimens were prepared with cement paste with diameter $28.00 \mathrm{~mm}$ and height $55.00 \mathrm{~mm}$. A total of 360 test specimens were prepared with mixtures containing 0 (control), $0.55 \% ; 1.0 \% ; 1.5 \% ; 2.0 \%$ and $2.5 \%$ potassium dichromate in relation to the cement mass. Verification of the treatment method's efficiency was based on the results of the axial compression resistance, solubilization in distilled water, moisture content, and water absorption tests with test specimens at 7 and 28 days of curing. In all the checks, the concrete test specimens were prepared based on cement pastes with water/cement factor (w/c) equal to 0.40 (for every $100.00 \mathrm{~g}$ of cement, $40.00 \mathrm{~g}$ of water was added at ambient temperature), which is the minimum ratio for complete hydration of the cement paste [23].

After manual homogenization, the pastes were molded into cylindrical bodies with $28.00 \mathrm{~mm}$ diameter and $55.00 \mathrm{~mm}$ height. They were also identified and taken to the curing environment, as shown in Figure 1. The adapted chamber was kept in a place protected from excessive heat and at room temperature and humidity. The curing environment consisted of a closed box with a volume of 
Table 1. Portland cement composition limits composed of pozzolanic material (\%).

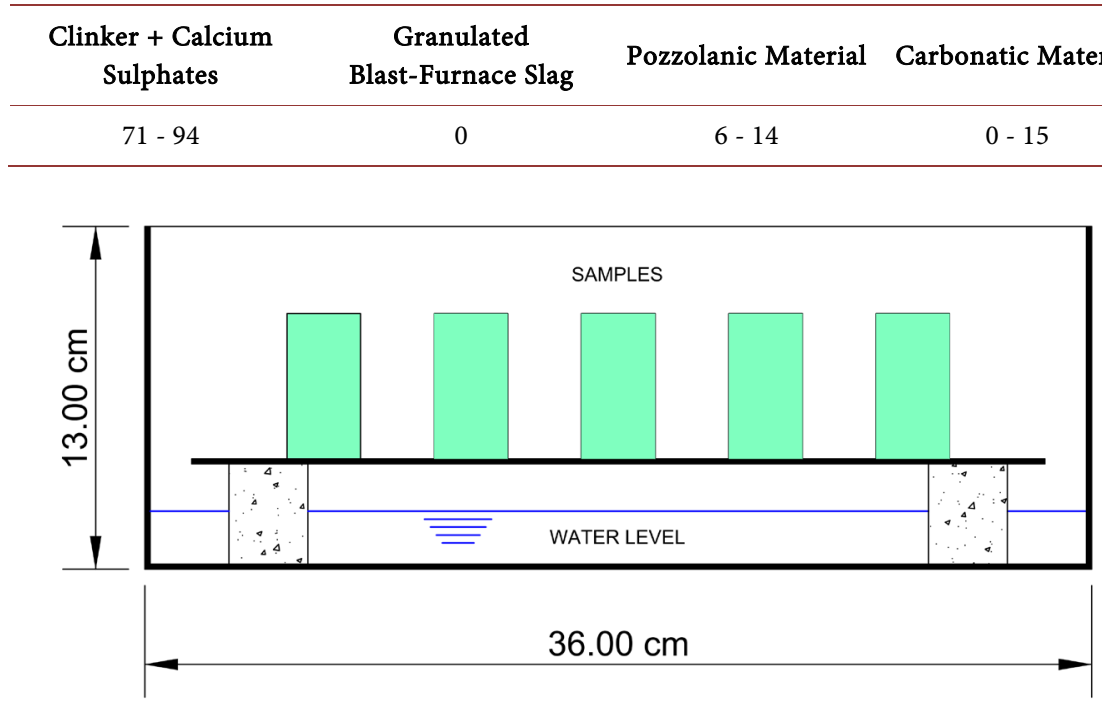

Figure 1. Adapted chamber for the work's development.

$0.011 \mathrm{~m}^{3}$. The resting surface supports consisted of $3.00 \mathrm{~cm}$ high mortar cement blocks. The environment was checked over the curing period to maintain a water level of approximately $2.00 \mathrm{~cm}$. An example of test specimen is shown in Figure 2.

Determination of moisture content. To determine the moisture content of the compositions, three test specimens were prepared for each mixture and for each curing period, 7 and 28 days, considering the average moisture content of each composition as the three determinations' average. After the curing period, the test specimens mass was determined, thus obtaining the gross mass $\left(M_{0}\right)$, and then taken to the oven at $100.0^{\circ} \mathrm{C}$ until reaching a constant mass. At the end of the drying process, the sample dry mass $\left(M_{1}\right)$ was determined on a precision scale. With this, the moisture content $(U)$ of each test specimen, expressed in percentage (weight percentage), was calculated using Equation (1):

$$
U=\frac{M_{0}-M_{1}}{M_{1}} \times 100
$$

Test of water absorption: Water absorption is a measure that relates directly to the volume of pores in the cementitious matrix, and in this work, it was analyzed by total immersion. After the curing period, the test specimens were taken to the oven at $100.0^{\circ} \mathrm{C}$ until reaching a constant mass, determining the dry mass $\left(M_{1}\right)$. They were then immersed in water at room temperature for $72 \mathrm{~h}$. At the end of the process, the test specimens were removed from the immersion tank, washed, and weighed on a precision scale, thus obtaining the wet mass $\left(M_{2}\right)$. With this, the water absorption content of each test specimen $(A)$, expressed in percentage (weight percentage), was calculated using Equation (2):

$$
A=\frac{M_{2}-M_{1}}{M_{1}} \times 100
$$




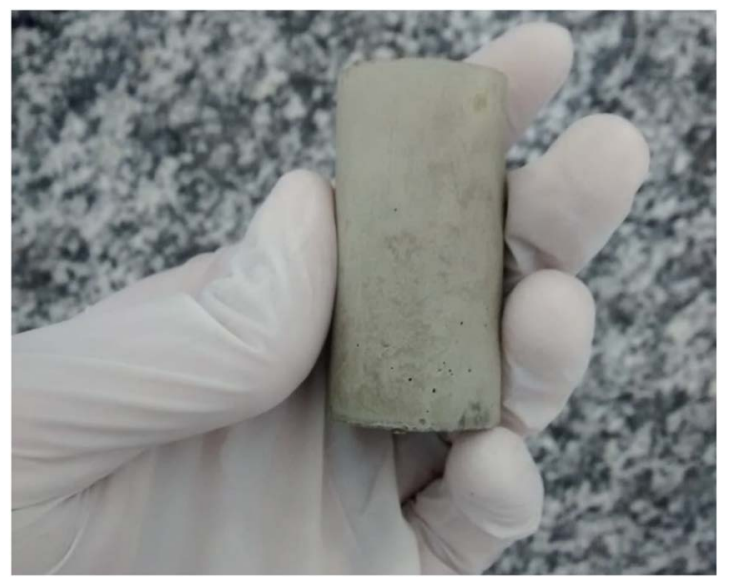

Figure 2. Test specimen.

The mean value of water absorption for each mixture at each curing period was obtained by the average of three determinations.

Determination of axial compressive strength: After the curing period, the surface of the test specimens was rectified, and three specimens of each composition from each curing period were subjected to an axial compressive strength test in a universal test machine, with a speed of $2.00 \mathrm{~mm} \cdot \mathrm{min}^{-1}$ (constant deformation). The average resistance of each mixture was obtained considering the average of three determinations for each curing period.

Solubilization test. For the evaluation of contaminant immobilization, dynamic solubilization tests were performed with monolithic samples. For the test, a sample of the material was placed in a container with distilled water. The samples remained in rest for a period of seven days at a temperature of $25.0^{\circ} \mathrm{C}$, and a determination of the extract concentration was done in every $24 \mathrm{~h}$, followed by the transfer of the specimen to another container with distilled water. The solubilization tests were conducted in triplicate for each mixture in the two curing periods. A volume of $200 \mathrm{~mL}$ of distilled water was fixed for the test. The extracts analysis was performed using spectrophotometry in the ultraviolet-visible region [24] [25]. The sample absorbance $(A)$ is given by Equation (3):

$$
A=\varepsilon_{\lambda} \times C \times l
$$

where $\mathcal{E}_{\lambda}$ is the molar extinction coefficient of the sample for addition of wavelength $\lambda$ (expressed in $\mathrm{L} \cdot \mathrm{mol}^{-1} \cdot \mathrm{cm}^{-1}$ ), $C$ is the chromophore concentration in the sample in $\mathrm{mol} \cdot \mathrm{L}^{-1}$, and $l$ is the optical path in $\mathrm{cm}$.

In order to determine chromium (VI) concentration in solubilized extracts, an analytical curve was obtained for potassium dichromate associated with Portland cement with pozzolan addition (CP II Z). For this purpose, the spectrophotometer was calibrated to $0 \%$ absorbance using a mixture of Portland cement and distilled water (the solvent used in the preparation of solutions). To verify the concentration of the extracts obtained in each immersion cycle in the solubilization test, the equipment was calibrated to $0 \%$ absorbance using the solubilized extract of a test specimen with no addition of potassium dichromate. The effi- 
ciency of chromium (VI) immobilization in each of the compositions was determined by Equation (4):

$$
E=\left(1-\frac{C_{\text {extrato }}}{C_{\text {pasta }}}\right) \times 100
$$

where $E$ is the efficiency in percentage, $C_{\text {extrato }}$ is the accumulated concentration of chromium in the solubilized extract, and $C_{\text {pasta }}$ is the total chromium concentration in the paste. The spectroscopic measurements in the ultraviolet-visible region were performed in a Perkin Elmer's Lambda 25 spectrophotometer, using quartz cuvettes with a square cross-section and $1 \mathrm{~cm}$ length (optical path). The results of this test indicate the potential of chromium leaching after the cement solidification in an aqueous medium.

Statistical analysis. For the statistical analyses, the free software Paleontological Statistics (PAST) Version 3.22 was used. All determinations were performed in triplicate and the parameters obtained were submitted to analysis of variance (ANOVA), test of multiple comparisons of means (Tukey's test), and Student's $\mathrm{t}$-test at a significance level $(p)$ of 0.05 . If $p \leq 0.05$, there is a significant difference at a $95 \%$ confidence level, and if $p>0.05$, it is indicated that there are no significant differences. Analysis of variance was performed with the objective to identify the existence of significant differences between the mixtures, and the Tukey's test aimed to identify which mixtures presented significant difference. The Student's t-test, conducted assuming different variances between mixtures, was done to verify the existence of significant difference between the curing periods.

\section{Results and Discussion}

Moisture content and water absorption: From the analysis of the results shown in the graph in Figure 3, it is observed that as the potassium dichromate content in the paste increased, there was also an increase in the moisture content (weight percentage) at the end of the curing period, demonstrating the influence of salt on the reactions of cement's hydration and solidification. All mixtures with an addition of potassium dichromate have a moisture content of more than $20 \%$ during both curing periods. The Tukey's test showed that in the two periods evaluated, the control sample (with no addition) differs from the other compositions with potassium dichromate $(p<0.05)$. Although there is a reduction in the moisture content of compositions with an increase in curing time, the results of the $\mathrm{t}$-test show that this variation is not significant $(p>0.05)$.

Wang and Vipulanandan [26] studied chromium's solidification-stabilization process (VI) with cement and observed through X-Ray diffraction that hexavalent chromium inhibits the hydration process by reacting with calcium $\left(\mathrm{Ca}^{2+}\right)$ present in the cement, forming calcium chromate $\left(\mathrm{CaCrO}_{4}\right)$. Such influence is reinforced when analyzing the variation of the setting time [27] of pastes containing this same type of addition. Wang \& Vipulanandan [26] and Cheng et al. [28] found that an increase of chromium (VI) concentration in Portland cement pastes increases the starting and ending of the setting time. The influence of the 


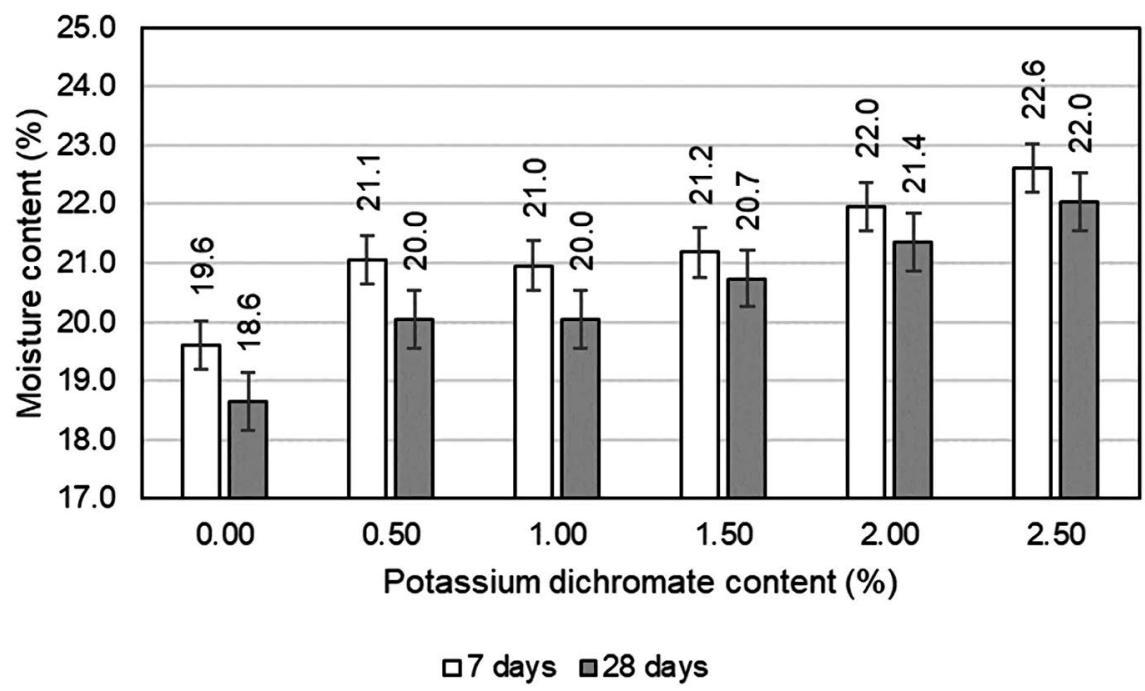

Figure 3. Moisture content at the end of the curing period.

addition of potassium dichromate on the cement's hydration and solidification reactions, besides interfering with the moisture content, also influences the porosity of the material. The results obtained in the immersion water absorption test for the two curing periods are shown on the graph in Figure 4, and these relate directly to the porosity of the specimens.

Since the addition of potassium dichromate impairs hydration reactions, the chromium-containing samples showed higher water content in their composition at the end of the curing period, as well as a higher porosity, which justifies the results presented. Observing the data in Figure 4, a reduction in water absorption is observed with the increase in curing time for all mixtures, which is related to the hydration of the cement over time. According to the results obtained in the Tukey's test, the water absorption of the control sample only presents significant difference in relation to the test specimens with 2.00 and $2.50 \%$ potassium dichromate in its composition at 7 curing days $(p<0.05)$. At 28 curing days, the control sample shows significant differences with all other compositions regarding water absorption $(p<0.05)$. The statistical analysis also shows that the reduction of water absorption over time is significant for all compositions $(p<0.05)$, demonstrating the positive effect of curing time associated with this aspect. The results also allow the reaffirmation of the deleterious effect of potassium dichromate in cement hydration reactions, which directly influences matrix porosity. In any case, it is worth noting that the damage caused to the matrix as a function of the amount of salt added is small. The increase of the potassium dichromate content in the composition by $2.50 \%$ (addition of $2.50 \%$ ) increases the water absorption capacity of the matrix by only $6.00 \%$.

Compressive strength: The mean compressive strength values of Portland cement pastes at ages 7 and 28 days are shown in Figure 5.

In general, it is observed that the compositions present a resistance gain with the increase of curing time, however the addition of potassium dichromate in 


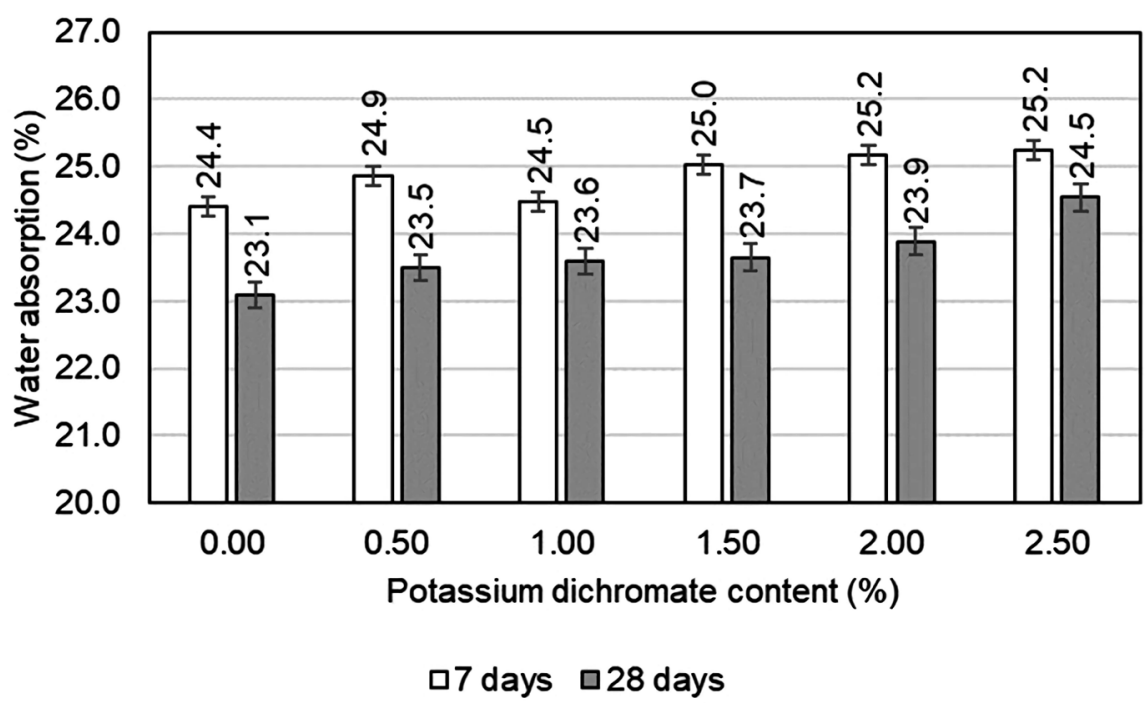

Figure 4. Water absorption by immersion.

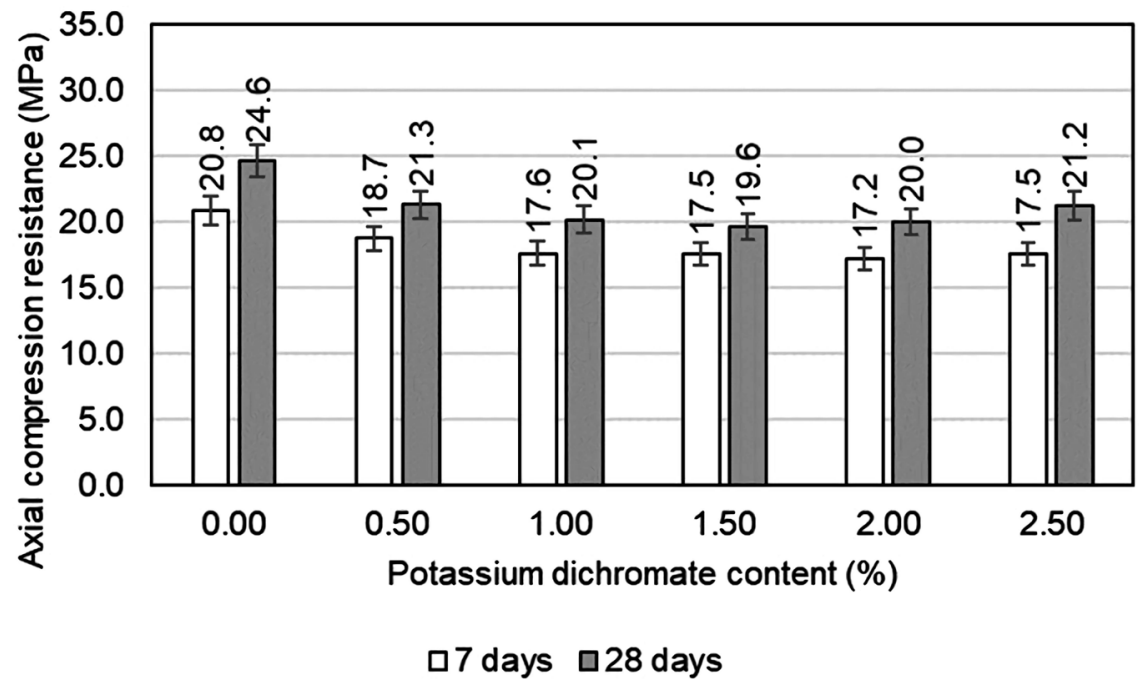

Figure 5. Compressive strength of mixtures.

the composition of the paste causes a resistance loss. At 7 curing days, the addition of potassium dichromate in the cement paste can cause a loss of resistance of the order of 3.0 MPa in relation to the control sample, and at 28 days this reduction is of the order of 5.0 MPa, which demonstrates the harmful effect of salt, not only on the mechanical performance of the material, but also in the reactions responsible for the resistance gain over time.

The statistical results obtained by ANOVA for compressive strength analysis showed that there is no significant difference between the six compositions in the two curing periods $(p>0.05)$. Comparing the mean values of compressive strength obtained in the two curing periods by the Student's t-test, one can observe the harmful effect of the addition of potassium dichromate in the reactions responsible for the resistance gain. The analysis of the parameters obtained in this statistical test shows that there is only a significant difference between the 
resistance values obtained at 7 and 28 curing days for the mixture that does not contain potassium dichromate in its composition, i.e., among the resistance gains represented in Figure 5, only the resistance gain of the control sample is significant $(p<0.05)$.

In their study on the influence of potassium dichromate on the behavior of aluminous cement, Ivanov et al. [7] observed a similar behavior. According to the results obtained by the authors, the addition of potassium dichromate promoted significant reductions in resistance values, attributed to inhibition and delay of cement hydration. Pinto et al., [29] in their study on stabilization by solidification of tannery residue, also observed that the increase in the amount of residue incorporated in the matrix promotes a reduction in compressive strength, since the reaction of chromium with cement slows the formation of calcium hydroxide crystals (portlandite), which contribute to the strength properties of the cementitious matrix [30].

The development of mechanical strength of a cement paste results from the hydration of the cement, specifically tricalcium and bicalcium silicates ( $3 \mathrm{CaO} \cdot \mathrm{SiO}_{2}$ and $2 \mathrm{CaO} \cdot \mathrm{SiO}_{2}$, respectively). This reaction results in the formation of calcium silicate and portlandite $\left(3 \mathrm{CaO} \cdot 2 \mathrm{SiO}_{2} \cdot 3 \mathrm{H}_{2} \mathrm{O}\right.$ and $\mathrm{Ca}(\mathrm{OH})_{2}$, respectively) and can be reported as the Equation (5) and Equation (6).

$$
\begin{gathered}
2\left(3 \mathrm{CaO} \cdot \mathrm{SiO}_{2}\right)+6 \mathrm{H}_{2} \mathrm{O} \rightarrow 3 \mathrm{CaO} \cdot 2 \mathrm{SiO}_{2} \cdot 3 \mathrm{H}_{2} \mathrm{O}+3 \mathrm{Ca}(\mathrm{OH})_{2} \\
2\left(2 \mathrm{CaO} \cdot \mathrm{SiO}_{2}\right)+4 \mathrm{H}_{2} \mathrm{O} \rightarrow 3 \mathrm{CaO} \cdot 2 \mathrm{SiO}_{2} \cdot 3 \mathrm{H}_{2} \mathrm{O}+\mathrm{Ca}(\mathrm{OH})_{2}
\end{gathered}
$$

The addition of chromium to the cement paste, compromises the formation of calcium silicate and portlandite. Because of the basic $\mathrm{pH}$ of cement paste, the most prominent $\mathrm{Cr}$ (VI) specie is $\mathrm{CrO}_{4}^{2-}$ [26]. The possible reaction between $\mathrm{Cr}(\mathrm{VI})$ and cement can be reported as Equation (7)

$$
\mathrm{Ca}^{2+}+\mathrm{CrO}_{4}^{2-} \stackrel{\text { high pH }}{\rightarrow} \mathrm{CaCrO}_{4}
$$

Solubilization: To determine chromium (VI) concentration in solubilized extracts, an analytical curve was constructed from a standard solution of distilled water and potassium dichromate with a concentration of $1.78 \times 10^{-4} \mathrm{~mol} \cdot \mathrm{L}^{-1}$. Figure 6(a) shows a representative absorption spectrum of potassium dichromate solution in distilled water in the ultraviolet $(200-350 \mathrm{~nm})$ and visible (350 - $700 \mathrm{~nm}$ ) regions. From this solution, 5 dilutions were made with cement addition, in order to obtain points for the construction of the potassium dichromate analytical curve with CP II-Z 32. Because they are solutions, the factor water cement was high, maintaining in all dilutions a ratio w/c equal to 500 . The 5 solutions were analyzed in a spectrophotometer at the visible-ultraviolet region to obtain the absorption spectrum. Absorption peaks were observed at $274 \mathrm{~nm}$ and $372 \mathrm{~nm}$ wavelengths, as shown in Figure 6(b). The peak displacements observed were also verified by por Costa et al., [31] and according to the authors, this behavior refers to the conversion of dichromate ions into chromate ions, influenced by the $\mathrm{pH}$ change of the solution promoted by the addition of cement. 
(a)

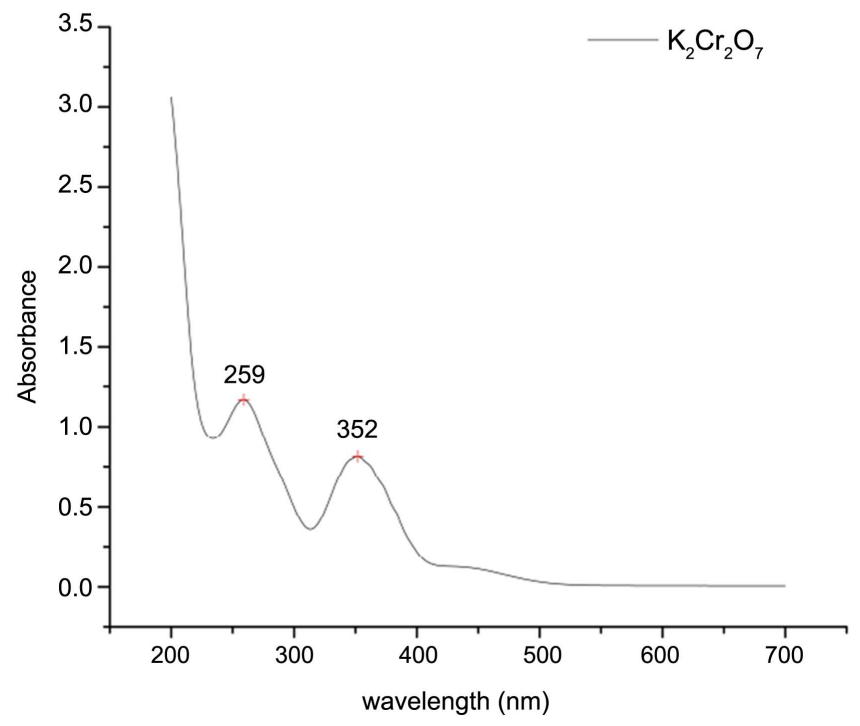

(b)

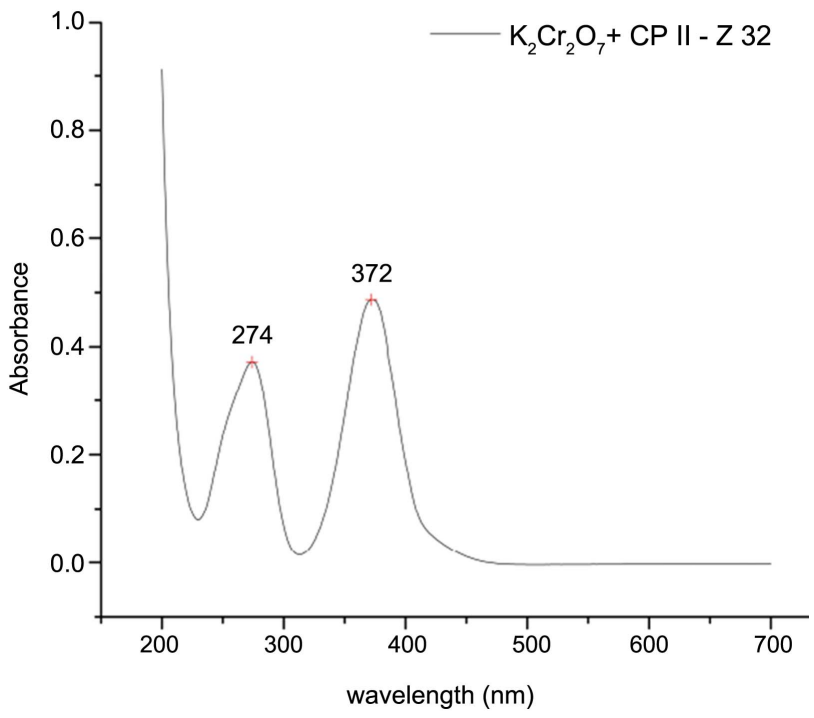

Figure 6. (a) Representative absorption spectrum in the ultraviolet $(200-350 \mathrm{~nm})$ and visible $(350-700 \mathrm{~nm})$ region of the potassium dichromate solution with distilled water (b) Representative absorption spectrum in the ultraviolet $(200-350 \mathrm{~nm})$ and visible (350 - $700 \mathrm{~nm}$ ) region of the potassium dichromate solution with Portland cemen.

For the construction of the analytical curve, the absorbance values of the verified solutions for the wavelength of $372 \mathrm{~nm}$ were considered. The composition of the solutions used to construct the analytical curve is presented in Table 2 and the analytical curve is presented in Figure 7.

The chromium (VI) concentrations verified in the solubilization extracts of the test specimens containing potassium dichromate addition at 7 and 28 curing days are shown in Table 3 and the graphic representation of the concentration variation during the periods of analysis is presented in Figure 8.

The analysis of the curves Figure 8(a) reveals that over time concentration of solubilized extracts obtained with samples after 7 curing days decreases to the same minimal point. In fact, the values obtained in the Tukey's test in the analysis of this parameter show that in the first 6 immersion cycles, with the exception of the extracts obtained from the samples with $0.50 \%$ and $1.00 \% \mathrm{~K}_{2} \mathrm{Cr}_{2} \mathrm{O}_{7}$, all other extracts present a significant difference among themselves $(p<0.05)$. The analysis also reveals that the concentration of the extracts obtained at the end of the seventh immersion cycle does not differ significantly between the closest addition levels, proving the convergent behavior. Unlike in the 7 days sample, the curves that represent the variation in the concentration of solubilized extracts at 28 curing days Figure 8(b), despite being parallel at the end of the test, do not converge to the same point. This fact is associated with the evolution of cement hydration that promotes the reduction of porosity and, consequently, the permeability of the matrix [32]. Thus, the lack of convergence of the curves presented in Figure $8(\mathrm{~b})$ is related to the fact that at 28 days the cement paste becomes less permeable, making water access difficult for the solubilization of the components of the mixture. The variation of the extracts' concentration over 
Table 2. Composition of the solutions used to obtain the analytical curve.

\begin{tabular}{ccccccc}
\hline \multirow{2}{*}{ POINT } & $\begin{array}{c}\text { SOLUTION VOL. } \\
\text { STANDARD }(\mathrm{mL})\end{array}$ & $\begin{array}{c}\text { VOLUME } \\
\text { DILUTION }(\mathrm{mL})\end{array}$ & CEMENT (g) & CONC. $\left(\mathrm{mol}^{-1} \mathrm{~L}^{-1}\right)$ & WATER/CEMENT & ABSORBANCE. \\
\hline 1 & 5.00 & 100.00 & 0.20 & $8.91 \mathrm{E}-05$ & 500 & 0.7893 \\
2 & 11.00 & 25.00 & 0.05 & $7.84 \mathrm{E}-05$ & 500 & 0.7049 \\
3 & 10.00 & 25.00 & 0.05 & $7.12 \mathrm{E}-05$ & 500 & 0.6206 \\
4 & 10.00 & 50.00 & 0.10 & $3.56 \mathrm{E}-05$ & 500 & 0.3285 \\
5 & 10.00 & 100.00 & 0.20 & $1.78 \mathrm{E}-05$ & 500 & 0.1533 \\
Auto-zero & 0.00 & 50.00 & 0.10 & - & 500 & - \\
\hline
\end{tabular}

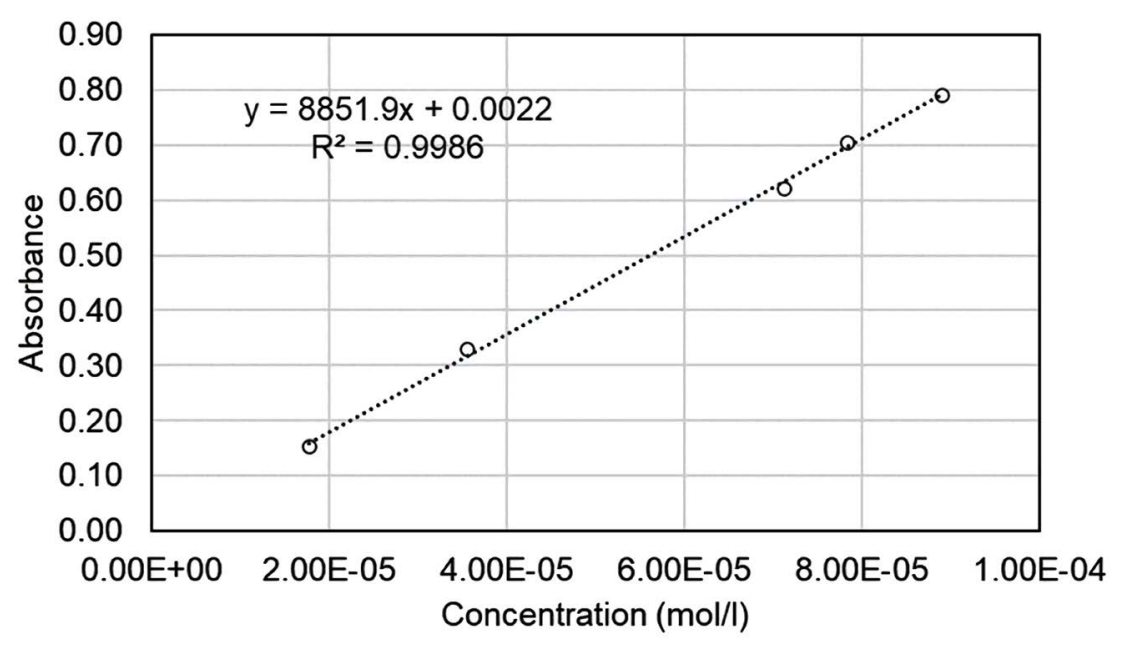

Figure 7. Analytical curve for the mixture of potassium dichromate with CP II-Z 32.
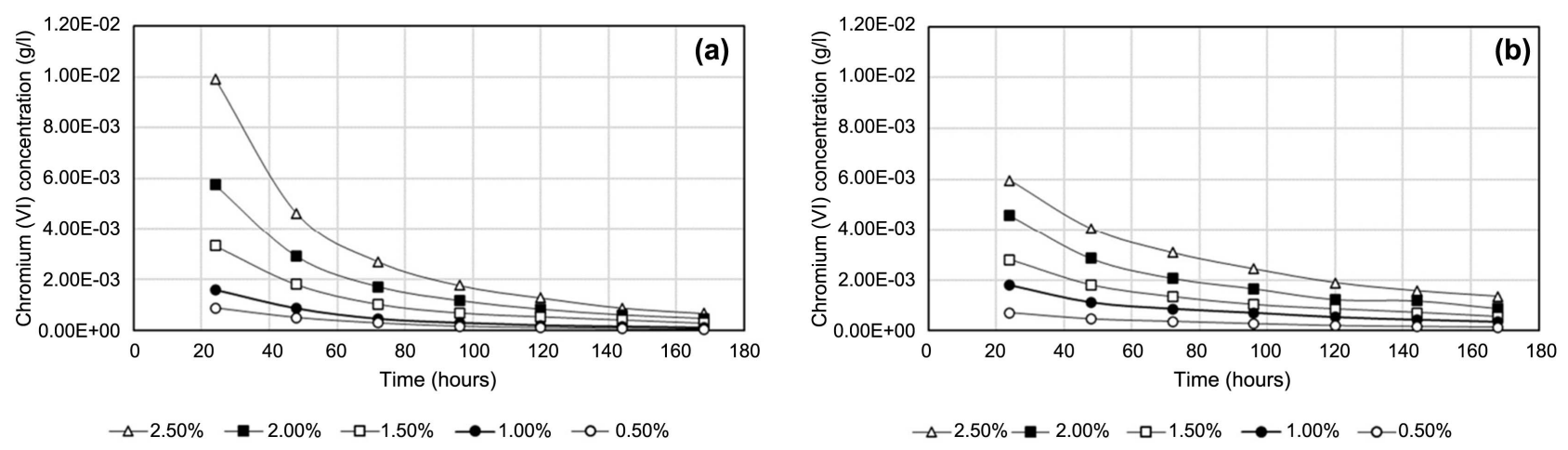

Figure 8. Variation of chromium (VI) concentration of solubilized extracts of samples at 7(a) and 28(b) curing days.

time can also be observed in Figure 9, which represents the variation of the solubilized extracts' absorbance with the advancement of the immersion cycles at 7 and 28 curing days. The absorption spectra presented refer only to the mixture with $2.5 \%$ potassium dichromate addition, but all compositions presented the same behavior, as can be observed in Table 3 .

The efficiency of the chromium (VI) immobilization process was determined based on the amount of chromium released throughout the solubilization test. 

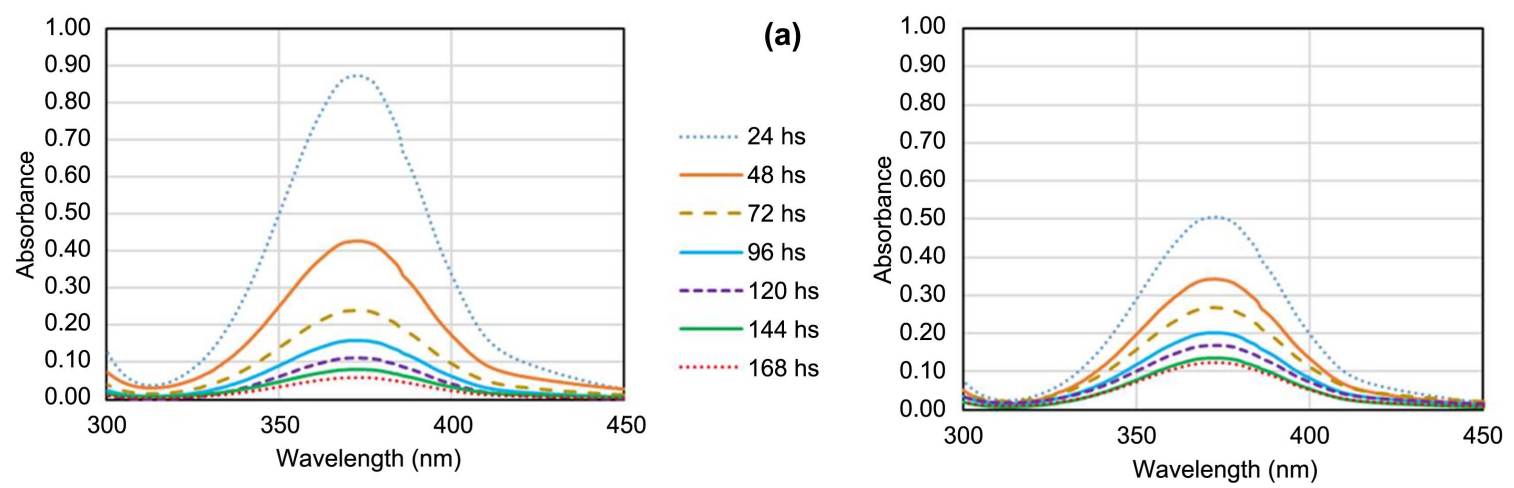

(b)

Figure 9. Variation of absorbance verified in sample extracts with $2.5 \%$ potassium dichromate at 7 (a) and 28(b) curing days during the solubilization test

Table 3. Chromium (VI) concentration $\left(\mathrm{g} \cdot \mathrm{L}^{-1}\right)$ found in solubilized extracts of samples at 7 and 28 curing days.

\begin{tabular}{|c|c|c|c|c|c|}
\hline \multirow{2}{*}{$\begin{array}{l}\text { TIME } \\
\text { (hours) }\end{array}$} & \multicolumn{5}{|c|}{ POTASSIUM DICHROMATE CONTENT (\%) 7 DAYS } \\
\hline & 0.50 & 1.00 & 1.50 & 2.00 & 2.50 \\
\hline 24 & $7.04 \mathrm{E}-04$ & $1.78 \mathrm{E}-03$ & $2.80 \mathrm{E}-03$ & $4.56 \mathrm{E}-03$ & $5.96 \mathrm{E}-03$ \\
\hline 48 & $4.62 \mathrm{E}-04$ & $1.11 \mathrm{E}-03$ & $1.80 \mathrm{E}-03$ & $2.84 \mathrm{E}-03$ & $4.04 \mathrm{E}-03$ \\
\hline 72 & $3.65 \mathrm{E}-04$ & $8.53 \mathrm{E}-04$ & $1.33 \mathrm{E}-03$ & $2.06 \mathrm{E}-03$ & $3.07 \mathrm{E}-03$ \\
\hline 96 & $2.76 \mathrm{E}-04$ & $6.98 \mathrm{E}-04$ & $1.02 \mathrm{E}-03$ & $1.65 \mathrm{E}-03$ & $2.43 \mathrm{E}-03$ \\
\hline 120 & $2.00 \mathrm{E}-04$ & $5.28 \mathrm{E}-04$ & $8.45 \mathrm{E}-04$ & $1.23 \mathrm{E}-03$ & $1.89 \mathrm{E}-03$ \\
\hline 144 & $1.63 \mathrm{E}-04$ & $4.26 \mathrm{E}-04$ & 7.07E-04 & $1.18 \mathrm{E}-03$ & $1.57 \mathrm{E}-03$ \\
\hline 168 & $1.37 \mathrm{E}-04$ & $3.44 \mathrm{E}-04$ & $5.40 \mathrm{E}-04$ & $8.69 \mathrm{E}-04$ & $1.35 \mathrm{E}-03$ \\
\hline \multirow{2}{*}{$\begin{array}{c}\text { TIME } \\
\text { (hours) }\end{array}$} & \multicolumn{5}{|c|}{ POTASSIUM DICHROMATE CONTENT (\%) 28 DAYS } \\
\hline & 0.50 & 1.00 & 1.50 & 2.00 & 2.50 \\
\hline 24 & $8.71 \mathrm{E}-04$ & $1.60 \mathrm{E}-03$ & $3.32 \mathrm{E}-03$ & $5.76 \mathrm{E}-03$ & $9.92 \mathrm{E}-03$ \\
\hline 48 & $4.93 \mathrm{E}-04$ & $8.54 \mathrm{E}-04$ & $1.80 \mathrm{E}-03$ & $2.91 \mathrm{E}-03$ & $4.64 \mathrm{E}-03$ \\
\hline 72 & $2.79 \mathrm{E}-04$ & $4.43 \mathrm{E}-04$ & $1.02 \mathrm{E}-03$ & $1.71 \mathrm{E}-03$ & $2.70 \mathrm{E}-03$ \\
\hline 96 & $1.50 \mathrm{E}-04$ & $2.83 \mathrm{E}-04$ & $6.79 \mathrm{E}-04$ & $1.16 \mathrm{E}-03$ & $1.76 \mathrm{E}-03$ \\
\hline 120 & $9.56 \mathrm{E}-05$ & $1.81 \mathrm{E}-04$ & $5.27 \mathrm{E}-04$ & $8.23 \mathrm{E}-04$ & $1.27 \mathrm{E}-03$ \\
\hline 144 & $6.85 \mathrm{E}-05$ & $1.35 \mathrm{E}-04$ & $4.02 \mathrm{E}-04$ & $5.96 \mathrm{E}-04$ & $8.72 \mathrm{E}-04$ \\
\hline 168 & $3.82 \mathrm{E}-05$ & $9.04 \mathrm{E}-05$ & $2.78 \mathrm{E}-04$ & $4.59 \mathrm{E}-04$ & $6.60 \mathrm{E}-04$ \\
\hline
\end{tabular}

Table 4 shows the efficiency of the immobilization process for each potassium dichromate content in each curing period, calculated according to Equation (4).

Table 4 shows the performance of CP II-Z 32 in the chromium (VI) immobilization process, for the potassium dichromate contents evaluated in this study, and for all mixtures the process efficiency was higher than $99.00 \%$. Similar to the values presented, Ivanov et al. [7]. Also observed a reduction in the efficiency of chromium retention with an increase in the concentration of potassium dichromate in cement matrices. Considering the presented values and the low solubility 
Table 4. Efficiency of immobilization.

\begin{tabular}{cccccc}
\hline \multirow{2}{*}{$\begin{array}{c}\mathrm{K}_{2} \mathrm{Cr}_{2} \mathrm{O}_{7} \\
\text { CONTENT (\%) }\end{array}$} & $\begin{array}{c}\text { INITIAL } \\
\text { CONCENTRATION } \\
\text { - PASTE }\left(\mathrm{g} \cdot \mathrm{L}^{-1}\right)\end{array}$ & \multicolumn{2}{c}{$\begin{array}{c}\text { FINAL CONCENTRATION - } \\
\text { EXTRACT }\left(\mathrm{g} \cdot \mathrm{L}^{-1}\right)\end{array}$} & \multicolumn{2}{c}{ EFFICIENCY (\%) } \\
\cline { 5 - 7 } 0.50 & 4.42 & $1.98 \mathrm{E}-03$ & $2.31 \mathrm{E}-03$ & 99.96 & 99.95 \\
1.00 & 8.84 & $3.59 \mathrm{E}-03$ & $5.74 \mathrm{E}-03$ & 99.96 & 99.94 \\
1.50 & 13.26 & $8.02 \mathrm{E}-03$ & $9.03 \mathrm{E}-03$ & 99.94 & 99.93 \\
2.00 & 17.67 & $1.34 \mathrm{E}-02$ & $1.44 \mathrm{E}-02$ & 99.92 & 99.92 \\
2.50 & 22.09 & $2.18 \mathrm{E}-02$ & $2.03 \mathrm{E}-02$ & 99.90 & 99.91 \\
\hline
\end{tabular}

of the calcium chromate [26], supposedly formed (Equation (7)), it can be inferred that the immobilization of Cr (VI) by solidification-stabilization was satisfactory. The treatment is able to reduce the hazardousness of wastes containing chromium. According to NBR 10004 [2] the chromium concentration in the solubilized extract must be less than $5.00 \times 10^{-5} \mathrm{~g} \cdot \mathrm{L}^{-1}$, but none of the evaluated compositions in the present study met this criterion. In the meantime, considering the parameters described in the normative instruction IN n 27/2006 of the Agriculture Ministry and Supply [33] which deals with the metal content of fertilizers, the values observed at the end of the experiment meet the permitted level that could be found in the soil (up to $500.00 \mathrm{mg} \cdot \mathrm{Kg}^{-1}$ ).

The correction of the material regarding the concentration of solubilized extracts can be made through the association of other binders and the use of porosity and permeability reducers. As an example of a porosity reducer, bentonite can be cited, which increases in volume when hydrating, obstructing the passage of water through the pores or cracks in the cement matrix [32]. Clays can also be added to the paste to favor the immobilization process, since they can adsorb the metals present in the residues and aid in the mechanical resistance, occupying empty spaces between the hydrated cement components [29]. The association of binders, such as lime and cement, can favor the encapsulation of waste. The addition of lime can reduce the leaching of contaminants due to the formation of calcium carbonate (calcite), which seals the pores of the cementitious matrix, and the formation of precipitates and other insoluble components [34].

\section{Conclusion}

The results of axial compression resistance demonstrate that the presence of potassium dichromate, in addition to causing a loss of resistance in relation to the control sample (with no addition), also impairs the reactions responsible for the development of resistance over time. This fact is confirmed by the results of the Student's t-test, which shows that there is no significant difference between the mean values of compressive strength obtained at 7 and 28 days in all mixtures containing potassium dichromate. It was also possible to observe an increase in the average water absorption value of the mixtures as the salt content in the composition increased. Considering the two periods evaluated, it was not possi- 
ble to notice a significant influence of curing time in the immobilization process, only a greater initial resistance to leaching that was neutralized during the solubilization test. Considering the results presented, it is observed that the addition of potassium dichromate in the cement matrix does not bring any beneficial effect to the cement behavior as a constructive material. In the meantime, the results of the solubilization test (efficiency in the immobilization process higher than $99.00 \%$ for all compositions in the two evaluated curing periods) reaffirm the capacity of this material as a solidifying agent for the treatment of chromium-contaminated wastes by solidification-stabilization. Due to the technique used to evaluate solubilized extracts, it was not possible to observe the behavior of the test specimens in periods of immersion greater than 168 hours in the solubilization test. At the end of the seventh cycle, the verified absorbance makes a satisfactory analysis impossible by resorting to the Lambert-Beer law, as can be observed in Figure 9 (absorbance less than 0.1). The present study evaluated the effect of the addition of potassium dichromate in some properties of Portland cement paste to verify the potential of chromium-containing residue treatment by solidification-stabilization. The results presented allow a better targeting of future studies, mainly regarding additions to improve the chemical stability of the obtained materials. Therefore, the incorporation of chromium-contaminated waste into Portland cement matrices requires further studies, of an interdisciplinary nature, especially in the areas of Chemistry and Environmental Engineering.

\section{Acknowledgements}

Federal University of Mato Grosso (UFMT), Materials Research Lab (LEMAt), FAPEMAT (227937/2015) and CAPES.

\section{Author Contributions}

Conceptualization, Wagner Santos; Data curation, Raul Lobato; Formal analysis, Raul Lobato; Funding acquisition, Wagner Santos; Investigation, Raul Lobato; Methodology, Raul Lobato, Fernanda Lira, Marizete Silva, Kelly Amorim, Dário Fortaleza; Project administration, Wagner Santos; Resources, Wagner Santos; Software, Raul Lobato, Kelly Amorim, Dário Fortaleza; Supervision, Wagner Santos; Validation, Raul Lobato; Visualization, Raul Lobato; Writing original draft, Raul Lobato; Writing review \& editing, Wagner Santos.

\section{Conflicts of Interest}

The authors declare that there are no conflicts of interest and that the study carried out here was not submitted to any other journal. We also declare that the authors approve the submission of the manuscript.

\section{References}

[1] Vieira, C.M.F., Andrade, P.M., Maciel, G.S., Vernilli Jr, F. and Monteiro, S.N. 
(2006) Incorporation of Fine Steel Sludge Waste into Red Ceramic. Materials Science and Engineering: A, 427, 142-147. https://doi.org/10.1016/j.msea.2006.04.040

[2] Associação Brasileira de Normas Técnicas; NBR 10.004 (2004) Resíduos sólidos: Classificação. Rio de Janeiro.

[3] Paul, D. (2017) Research on Heavy Metal Pollution of River Ganga: A Review. Annals of Agrarian Science, 15, 278-286. https://doi.org/10.1016/j.aasci.2017.04.001

[4] Edelstein, M. and Ben-Hur, M. (2018) Heavy Metals and Metalloids: Sources, Risks and Strategies to Reduce Their Accumulation in Horticultural Crops. Scientia Horticulturae, 234, 431-444. https://doi.org/10.1016/j.scienta.2017.12.039

[5] Kadirvelu, K., Thamaraiselvi, K. and Namasivayam, C. (2001) Removal of Heavy Metals from Industrial Wastewaters by Adsorption onto Activated Carbon Prepared from an Agricultural Solid Waste. Bioresource Technology, 76, 63-65. https://doi.org/10.1016/S0960-8524(00)00072-9

[6] Pellerin, C. and Booker, S.M. (2000) Reflections on Hexavalent Chromium: Health Hazards of an Industrial Heavyweight. Environmental Health Perspectives, 108, A402-A407. https://doi.org/10.1289/ehp.108-a402

[7] Ivanov, R.C., da Luz, C.A., Zorel Jr, H.E. and Pereira Filho, J.I. (2016) Behavior of Calcium Aluminate Cement (CAC) in the Presence of Hexavalent Chromium. $\mathrm{Ce}$ ment and Concrete Composites, 73, 114-122. https://doi.org/10.1016/j.cemconcomp.2016.07.006

[8] Bocanegra, J.J.C., Mora, E.E. and González, G.I.C. (2017) Encapsulation in Ceramic Material of the Metals $\mathrm{Cr}, \mathrm{Ni}$, and $\mathrm{Cu}$ Contained in Galvanic Sludge via the Solidification/Stabilization Method. Journal of Environmental Chemical Engineering, 5, 3834-3843. https://doi.org/10.1016/j.jece.2017.07.044

[9] Guo, B., Liu, B., Yang, J. and Zhang, S. (2017) The Mechanisms of Heavy Metal Immobilization by Cementitious Material Treatments and Thermal Treatments: A Review. Journal of Environmental Management, 193, 410-422. https://doi.org/10.1016/j.jenvman.2017.02.026

[10] Chen, M., Li, X.M., Yang, Q., Zeng, G.M., Zhang, Y., Liao, D.X. and Guo, L. (2008) Total Concentrations and Speciation of Heavy Metals in Municipal Sludge from Changsha, Zhuzhou and Xiangtan in Middle-South Region of China. Journal of Hazardous Materials, 160, 324-329. https://doi.org/10.1016/j.jhazmat.2008.03.036

[11] Brehm, F.A., Kulakowski, M.P., Evaldt, D.C., Moraes, C.A.M. and Pampanelli, A.B. (2013) Análise da estabilização por solidificação de lodo de fosfatização em matrizes de cimento Portland e de cerâmica vermelha para a utilização na construção civil. Ambiente Construído, 13, 15-27. https://doi.org/10.1590/S1678-86212013000200003

[12] Bae, S., Hikaru, F., Kanematsu, M., Yoshizawa, C., Noguchi, T., Yu, Y. and Ha, J. (2018) Removal of Hexavalent Chromium in Portland Cement Using Ground Granulated Blast-Furnace Slag Powder. Materials, 11, 11. https://doi.org/10.3390/ma11010011

[13] Gagg, C.R. (2014) Cement and Concrete as an Engineering Material: An Historic Appraisal and Case Study Analysis. Engineering Failure Analysis, 40, 114-140. https://doi.org/10.1016/j.engfailanal.2014.02.004

[14] Klemm, W. (1994) Hexavalent Chromium in Portland Cement. Cement, Concrete and Aggregates, 16, 43-47. https://doi.org/10.1520/CCA10560J

[15] Frías, M., Rojas, M.I.S., García, N. and Luxán, M.P. (1994) Contribution of Toxic 
Elements: Hexavalent Chromium in Materials Used in the Manufacture of Cement. Cement and Concrete Research, 24, 533-541. https://doi.org/10.1016/0008-8846(94)90142-2

[16] Matos, W.O. and Nóbrega, J.A. (2009) Especiação de cromo em cimentos e derivados de cimento brasileiros. Química Nova, 32, 2094-2097.

https://doi.org/10.1590/S0100-40422009000800020

[17] Ribeiro, D.V., Yuan, S.Y. and Morelli, M.R. (2011) Efeito da adição de serragem de couro tratada quimicamente nas proprie-dades do cimento Portland. Química Nova, 34, 979-983. https://doi.org/10.1590/S0100-40422011000600012

[18] Zhang, M., Yang, C., Zhao, M., Yu, L., Yang, K., Zhu, X. and Jiang, X. (2018) Immobilization of $\mathrm{Cr}(\mathrm{VI})$ by Hydrated Portland Cement Pastes with and without Calcium Sulfate. Journal of Hazardous Materials, 342, 242-251. https://doi.org/10.1016/j.jhazmat.2017.07.039

[19] Laforest, G. and Duchesne, J. (2005) Immobilization of Chromium (VI) Evaluated by Binding Isotherms for Ground Granulated Blast Furnace Slag and Ordinary Portland Cement. Cement and Concrete Research, 35, 2322-2332. https://doi.org/10.1016/j.cemconres.2004.12.011

[20] Stegemann, J.A. and Zhou, Q. (2009) Screening Tests for Assessing Treatability of Inorganic Industrial Wastes by Stabilisation/Solidification with Cement. Journal of Hazardous Materials, 161, 300-306. https://doi.org/10.1016/j.jhazmat.2008.03.090

[21] Associação Brasileira de Normas Técnicas (2018) NBR 16.697 Cimento Portland: Requisitos. Rio de Janeiro.

[22] Macêdo, A.N., de Lima, A.M., Fonseca, F.D.O. and Lavôr, B.D.A. (2011) Análise estatística do comportamento mecânico à compressão do compósito cimento madeira. Matéria (Rio de Janeiro), 16, 658-667. https://doi.org/10.1590/S1517-70762011000200002

[23] Pann, K.S., Yen, T., Tang, C.W. and Lin, T.D. (2003) New Strength Model Based on Water-Cement Ratio and Capillary Porosity. ACI Materials Journal, 100, 311-318. https://doi.org/10.14359/12669

[24] Rocha, F.R. and Teixeira, L.S. (2004) Estratégias para aumento de sensibilidade em espectrofotometria UV-VIS. Química Nova, 27, 807-812. https://doi.org/10.1590/S0100-40422004000500021

[25] Galo, A.L. and Colombo, M.F. (2009) Espectrofotometria de longo caminho óptico em espectrofotômetro de duplo-feixe convencional: Uma alternativa simples para investigações de amostras com densidade óptica muito baixa. Química Nova, 32, 488-492. https://doi.org/10.1590/S0100-40422009000200036

[26] Wang, S. and Vipulanandan, C. (2000) Solidification/Stabilization of Cr(VI) with Cement: Leachability and XRD Analyses. Cement and Concrete Research, 30, 385-389. https://doi.org/10.1016/S0008-8846(99)00265-3

[27] Lei, W.G. and Struble, L.J. (1997) Microstructure and Flow Behavior of Fresh Cement Paste. Journal of the American Ceramic Society, 80, 2021-2028. https://doi.org/10.1111/j.1151-2916.1997.tb03086.x

[28] Cheng, S., Shui, Z., Yu, R., Zhang, X. and Zhu, S. (2018) Durability and Environment Evaluation of an Eco-Friendly Cement-Based Material Incorporating Recycled Chromium Containing Slag. Journal of Cleaner Production, 185, 23-31. https://doi.org/10.1016/j.jclepro.2018.03.048

[29] Pinto, C.A., Dweck, J., Sansalone, J.J., Cartledge, F.K., Hamassaki, L.T., Valenzuela-Díaz, F.R. and Büchler, P.M. (2010) Evaluation of S/S Process of Tannery Waste 
in Cement by Structural and Mechanical Analysis. Materials Science Forum, 660, 1130-1136. https://doi.org/10.4028/www.scientific.net/MSF.660-661.1130

[30] Ribeiro, D.V., Yuan, S.Y. and Morelli, M.R. (2012) Effect of Chemically Treated Leather Shaving Addition on Characteristics and Microstructure of OPC Mortars. Materials Research, 15, 136-143. https://doi.org/10.1590/S1516-14392012005000006

[31] Costa, L.D.S., Pereira, F.R.D.S., Farias, R.F.D. and Pereira, F.C. (2010) Avaliação espectrofotométrica das formas $\mathrm{Cr}^{+3}, \mathrm{CrO}^{4-}{ }_{2} \mathrm{e} \mathrm{Cr}_{2} \mathrm{O}_{7}{ }^{-2}$. Eclética Química, 35, 157-167. https://doi.org/10.1590/S0100-46702010000300016

[32] Darweesh, H.H.M. and Nagieb, Z.A. (2007) Hydration of Calcined Bentonite Portland Blended Cement Pastes. Indian Journal of Chemical Technology, 14, 301-307. http://nopr.niscair.res.in/handle/123456789/1124

[33] Brasil, Instrução Normativa SDA No 27, 05 de Junho de 2006 (Alterada pela IN SDA $\mathrm{n}^{\circ}$ 7, de 12/04/2016, republicada em 02/05/2016) 2006.

[34] Kundu, S. and Gupta, A.K. (2008) Immobilization and Leaching Characteristics of Arsenic from Cement and/or Lime Solidified/stabilized Spent Adsorbent Containing Arsenic. Journal of Hazardous Materials, 153, 434-443.

https://doi.org/10.1016/j.jhazmat.2007.08.073 